Original Article

\title{
Mycoviruses infecting Colletotrichum spp.: A comprehensive review
}

\author{
Micoviroses em Colletotrichum spp.: uma revisão abrangente
}

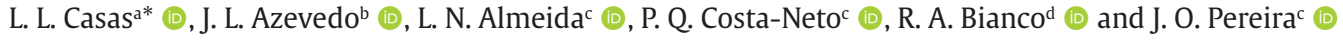 \\ anniversidade do Estado do Amazonas - UEA, Programa de Pós-graduação em Biodiversidade e Biotecnologia - Bionorte, Manaus, AM, Brasil \\ 'Universidade de São Paulo - USP, Escola Superior de Agricultura Luiz de Queiroz, Piracicaba, SP, Brasil \\ Universidade Federal do Amazonas - UFAM, Faculdade de Ciências Agrárias, Manaus, AM, Brasil \\ ¿Centro Universitário do Norte - Uninorte, Manaus, AM, Brasil
}

\begin{abstract}
Colletotrichum is one of the most economically important fungal genera, which affects a wide range of hosts, specifically tropical and subtropical crops. Thus far, there have been several records of mycovirus infection in Colletotrichum spp., primarily by viruses of the Partitiviridae family. There have also been records of infections by mycoviruses of the Chrysoviridae family. Mycoviruses are (+)ssRNA and dsRNA genome viruses, which may or may not be enveloped. To date, no mycovirus with a DNA genome has been isolated from Colletotrichum spp. Typically, mycoviruses cause latent infections, although hypo- and hypervirulence have also been reported in Colletotrichum spp. In addition to its effects on pathogenic behavior, mycovirus infection can lead to important physiological changes, such as altered morphological characteristics, reduced vegetative growth, and suppressed conidia production. Therefore, research on mycoviruses infecting phytopathogenic fungi can help develop alternative methods to chemical control, which can cause irreversible damage to humans and the environment. From an agricultural perspective, mycoviruses can contribute to sustainable agriculture as biological control agents via changes in fungal physiology, ultimately resulting in the total loss of or reduction in the virulence of these pathogens.

Keywords: agriculture, biological control, hypovirulence, phytopathology.

\section{Resumo}

Colletotrichum é um dos gêneros fúngicos mais importantes economicamente, afetando uma ampla gama de hospedeiros, especialmente em cultivos tropicais e subtropicais. Atualmente já existem diversos registros de infecção por micovírus em Colletotrichum spp., sendo a maioria dos já identificados classificados na família Partitiviridae. Ocorrem registros também de micovírus pertencentes à família Chrysoviridae. Compreendem vírus de genoma de (+)ssRNA e dsRNA que podem ser ou não envelopados. Ainda não foram identificados micovírus com genoma de DNA isolados de Colletotrichum. A infecção por micovírus pode ocorrer de forma latente, mas já foi observado em Colletotrichum spp. o fenômeno de hipo e hipervirulência. Além de influenciar no comportamento patogênico, a infecção pode causar mudanças fisiológicas importantes como alterações das características morfológicas, redução do crescimento vegetativo e redução na produção de conídios. O estudo com micovírus em fungos fitopatogênicos traz uma alternativa ao controle químico que é um método capaz de causar danos irreversíveis ao homem e o meio ambiente. Sob a perspectiva agrícola, os micovírus podem contribuir para agricultura sustentável como agentes de controle biológico. Isso porque obsevam-se mudanças importantes na fisiologia fúngica resultando na perda total ou redução da virulência desses patógenos.
\end{abstract}

Palavras-chave: agricultura, controle biológico, hipovirulência, fitopatologia.

\section{Introduction}

Mycoviruses are viruses that infect a wide array of fungal species. In 1962, while studying a disease in the edible mushroom Agaricus bisporus, Hollings reported the presence of viral particles within the fungus for the first time (Hollings, 1962). Subsequently, Banks et al. (1968) found that viral double-stranded RNA (dsRNA) particles present in Penicillium stoloniferum extracts induced the synthesis of interferon, an antiviral protein produced by animals, which triggered interest in these microorganisms (Buck, 1988; Picarelli et al., 2017).

Studies on mycovirus infection of the filamentous fungus Cryphonectria parasitica laid the foundation for future research into fungal hypovirulence or debilitation in other species (Ghabrial and Suzuki, 2009; Wu et al.,

*e-mail: luanacasas05@gmail.com

Received: February 21, 2021 - Accepted: May 7, 2021

This is an Open Access article distributed under the terms of the Creative Commons Attribution License, which permits unrestricted use, distribution, and reproduction in any medium, provided the original work is properly cited. 
2010; Eusebio-Cope et al., 2015; Kotta-Loizou and Coutts, 2017). The presence of virus in the host fungus can induce several physiological changes; for instance, the virus can reduce the virulence of its phytopathogenic fungal host, leading to hypovirulence. Hypovirulence induced by mycoviruses in plant pathogenic fungi can be transmitted within species through hypha between the compatible strains (Anagnostakis and Day, 1979).

Colletotrichum spp. are pathogenic fungi of great importance in the context of phytopathology, as they cause anthracnose in several plant species. They can infect a wide range of hosts, specifically tropical and subtropical crops as well as fruit trees (Sutton, 1992; Hyde et al., 2009). The disease can harm any part of the plant above the ground, such as stems, leaves, flowers, and fruits. Bailey and Jeger (1992) reported that Colletotrichum spp. could cause anthracnose in legumes; vegetables; and fructiferous species, such as mango, avocado, and papaya, from seedlings to adult trees.

Although several control measures against phytopathogens have already been tested, chemical control remains the gold standard (Dowling et al., 2020). Fungicide spraying, in addition to being expensive, is hazardous to the environment and humans. In this light, the use of mycoviruses as an alternative to control phytopathogenic fungi has attracted much attention. To this end, this article presents an overview of studies on mycoviruses infecting Colletotrichum spp., describing the occurrence of the major mycovirus families in the fungi of this genus and the effects of viruses on host physiology. In addition, we discuss mycoviruses in terms of their classification and transmission as well as virus-fungus interactions.

\section{Mycoviruses}

Mycoviruses often cause latent infections in their hosts. Moreover, they have no natural vectors (e.g., arthropods or annelids) and are typically transmitted horizontally via intracellular means (hyphal anastomosis) or vertically via spore spread (mitotic and sometimes meiotic spores). Thus, despite the lack of an extracellular phase in their life cycle, these viruses employ efficient and evidently successful means of horizontal and vertical transmission, being prevalent in all major groups of fungi such as Chytridiomycota, Zigomycota, Ascomycota, and Basidiomycota. The mycovirus incidence has been estimated to be $30-80 \%$ in their fungal hosts (Ghabrial and Suzuki, 2009; Pearson et al., 2009; Ghabrial et al., 2015). In some cases, mycoviruses can even insert themselves into the mitochondria during the latent infection phase (Pearson et al., 2009), producing adverse effects such as hypo- or hypervirulence (Vainio et al., 2018), or mutualistic effects (Márquez et al., 2007).

Viral taxonomy considers the following criteria for identification: molecular genome composition, capsid structure, envelope structure (when present), particle size and morphology, host range, pathogenicity, and percentage of similarity between genomic sequences (Picarelli et al., 2017; Lefkowitz et al., 2018). According to the International Committee on Taxonomy of Viruses (ICTV), mycoviruses are classified into 52 genera distributed in 16 families (Table 1 ).
Mycoviruses harbor different types of genomes, such as double-stranded RNA (dsRNA), single-stranded positive RNA [(+)ssRNA], single-stranded negative [(-)ssRNA], and single-stranded DNA (ssDNA) (Ghabrial et al., 2015).

\section{Mycovirus transmission}

Mycoviruses can be transmitted vertically or horizontally among fungi (Wang et al., 2016). Vertical transmission (from the stem to sexual or asexual spores) is the most common form of mycovirus spread. The virus transmission rate of $100 \%$ via asexual spore production has been reported, which hinders the isolation of isogenic strains without mycoviruses ("cure") (Leqoc Lecoq et al., 1979; Picarelli et al., 2017). Transmission via sexual spores is relatively rare (Pearson et al., 2009). The process of cure has already been observed in Trichoderma (Liu et al., 2019), Ceratobasidium (Cao et al., 2019), and Aspergillus (Özkan and Coutts, 2015) subjected to treatments with different chemical substances supplemented into the culture medium. Horizontal transmission through hyphal anastomosis occurs among vegetatively compatible fungal individuals. The process of cytoplasmic exchange transfers mycoviruses to uninfected hyphal cells (Wang et al., 2017).

Vegetative incompatibility (lack of cell recognition necessary for anastomosis) results in compartmentalization and subsequent lysis of the involved cells, similar to the hypersensitivity reaction in plants (Paoletti and Saupe, 2009). Therefore, vegetative incompatibility represents a major barrier to the horizontal transmission of mycoviruses. In brief, when the hyphae of two incompatible fungal strains fuse, recognition between cells does not occur. Subsequently, programmed cell death is initiated and cytoplasmic exchange fails, preventing the horizontal transmission of mycoviruses (Wang et al., 2017).

Although mycoviruses share some characteristics with animal and plant viruses, they show some distinct characteristics, as follows: (1) they do not have an extracellular route of infection; (2) they are transmitted between cells only through cell division, sporulation, and cytosolic fusion; and (3) they are apparently devoid of movement protein, which is essential for the life cycle of animal and plant viruses (Son et al., 2015).

\section{Mycovirus-host interaction}

Initially, the mycoviruses produce no signs. Therefore, they are considered the most latent viruses (Pearson et al., 2009). Nonetheless, mycovirus infection can alter the mycelial growth rate, in addition to other changes. van Diepeningen et al. (2006) reported marked differences in growth, spore production, and competitive ability between isogenic infected and uninfected Aspergillus strains.

According to Milgroom and Hillman (2011), vegetative incompatibility serves as a barrier to horizontal transmission; therefore, the dependence on vertical transmission has likely driven the evolution of mycovirus strains that do not induce positive or negative changes in the host. However, they observed that mycoviruses are in fact harmful based on the alterations that, albeit mildly, can interfere with the relationships between the virus and fungus as well as affect the growth, sporulation, 
Table 1. Current classification of mycoviruses.

\begin{tabular}{|c|c|c|c|c|}
\hline Nucleic acid & Genome organization & Family & Genera & Species \\
\hline \multirow[t]{8}{*}{ dsRNA } & $\begin{array}{l}\text { Isometric virions } 40 \mathrm{~nm} 1 \\
\text { segment } 4-6.7 \mathrm{kbp}\end{array}$ & Totiviridae & $\begin{array}{l}\text { Giardivirus, Leishmaniavirus, } \\
\text { Totivirus, Trichomonasvirus, } \\
\text { Victorivirus }\end{array}$ & 28 \\
\hline & $\begin{array}{l}\text { Isometric virions } 40 \mathrm{~nm} 2 \\
\text { segments } 1.4-2.4 \mathrm{kbp}\end{array}$ & Partitiviridae & $\begin{array}{l}\text { Alphapartitivirus, Betapartitivirus, } \\
\text { Cryspovirus, Deltapartitivirus, } \\
\text { Gammapartitivirus }\end{array}$ & 60 \\
\hline & $\begin{array}{l}\text { Isometric virions } 60-80 \mathrm{~nm} \\
10-12 \text { segments } 0.7-5 \mathrm{kbp}\end{array}$ & Reoviridae & $\begin{array}{l}\text { Subfamily: Sedoreovirinae: } \\
\text { Cardoreovirus, Mimoreovirus, } \\
\text { Orbivirus, Phytoreovirus, Rotavirus, } \\
\text { Seadornavirus } \\
\text { Subfamily: Spinareovirinae: } \\
\text { Aquareovirus, Coltivirus, Cypovirus, } \\
\text { Dinovernavirus, Fijivirus, } \\
\text { Idnoreovirus, Mycoreovirus, } \\
\text { Orthoreovirus, Oryzavirus }\end{array}$ & 97 \\
\hline & $\begin{array}{l}\text { Isometric virions } 40 \mathrm{~nm} 2 \\
\text { segments } 2.4-3.6 \mathrm{kbp}\end{array}$ & Crysoviridae & Alphachrysovirus, Betachrysovirus & 25 \\
\hline & $\begin{array}{l}\text { Lipids vesicles } 1 \text { segment } \\
14-17.6 \mathrm{kbp}\end{array}$ & Endornaviridae & Alphaendornavirus, Betaendornavirus & 31 \\
\hline & $\begin{array}{l}\text { Isometric virions } 48 \mathrm{~nm} 4 \\
\text { segments 3.7-4.9 kbp }\end{array}$ & Quadriviridae & Quadrivirus & 1 \\
\hline & $\begin{array}{l}\text { Isometric virions } 50 \mathrm{~nm} 2 \\
\text { segments 7-9 kbp }\end{array}$ & Megabirnaviridae & Megabirnavirus & 1 \\
\hline & $\begin{array}{l}\text { Isometric virions } 35 \mathrm{~nm} 2 \\
\text { segments 5.9-6.2 kbp }\end{array}$ & - & Botybirnarvirus & 1 \\
\hline \multirow[t]{5}{*}{ (+) ssRNA } & $\begin{array}{l}\text { Filamentous virions } 470- \\
800 \times 12-13 \mathrm{~nm} 1 \text { segment } \\
5.9-9 \mathrm{kp}\end{array}$ & Alphaflexiviridae & $\begin{array}{l}\text { Allexivirus, Botrexvirus, Lolavirus, } \\
\text { Mandarivirus, Platypuvirus, } \\
\text { Potexvirus, Sclerodarnavirus }\end{array}$ & 56 \\
\hline & $\begin{array}{l}\text { Lipids vesicles } 80 \times 50 \mathrm{~nm} 1 \\
\text { segment } 9-13 \mathrm{~kb}\end{array}$ & Hypoviridae & Hypovirus & 4 \\
\hline & $\begin{array}{l}\text { Unencapsidated } 1 \text { segment } \\
1.7-2.9 \mathrm{~kb}\end{array}$ & Narnaviridae & Narnavirus, Mitovirus & 2 \\
\hline & $\begin{array}{l}\text { Bacilliform virions } 50 \times 20 \\
\mathrm{~nm} 1 \text { segment } 4 \mathrm{~kb}\end{array}$ & Barnaviridae & Barnavirus & 1 \\
\hline & $\begin{array}{l}\text { Filamentous virions } 720 \times \\
12-13 \mathrm{~nm} 1 \text { segment } 6.8 \mathrm{~kb}\end{array}$ & Gammaflexiviridae & Mycoflexivirus & 1 \\
\hline \multirow{2}{*}{$\begin{array}{l}\text { Reverse- } \\
\text { transcribing } \\
\text { RNA viruses }\end{array}$} & $\begin{array}{l}\text { Round/ovoid virions } 1 \\
\text { segment } 4-10 \mathrm{~kb}\end{array}$ & Metaviridae & Errantivirus, Metavirus & 31 \\
\hline & $\begin{array}{l}\text { Round/ovoid virions } 1 \\
\text { segment 5-9 kb }\end{array}$ & Pseudoviridae & Hemivirus, Pseudovirus, Sirevirus & 34 \\
\hline$(-) s s R N A$ & $\begin{array}{l}\text { Filamentous virions } 300- \\
400 \times 20 \mathrm{~nm} 1 \text { segment } \\
10 \mathrm{~kb}\end{array}$ & Mymonaviridae & Hubramonavirus, Sclerotimonavirus & 9 \\
\hline$(-) s s D N A$ & $\begin{array}{l}\text { Isometric virions } 20-22 \mathrm{~nm} \\
1 \text { circular molecule } 2.2 \mathrm{~kb}\end{array}$ & Genomoviridae & Gemycircularvirus & 1 \\
\hline
\end{tabular}

This information has been derived from Virus Taxonomy: The Classification and Nomenclature of Viruses - The Online (10th) Report of the ICTV (2020).

and virulence of the fungus, in addition to reducing its abundance. In addition, environmental changes, fungal physiology, and concomitant infections may interfere with mycovirus virulence and transmissibility (Pearson et al., 2009; Picarelli et al., 2017).

The presence of mycoviruses in endophytic fungi is associated with the adaptation of plants to extreme conditions. Heat tolerance of Dichanthelium lanuginosum, which grows in geothermal soil, is induced by the presence of the mycovirus Curvularia sp. (Márquez et al., 2007).

Mycovirus infection can allow the host to infect other plant species. Entomopathogenic fungi, whose life cycle includes an endophytic phase on the wild grasses Festuca rubra and Holcus lanatus, acquired the ability to colonize 
other plants after being infected with mycoviruses (Herrero Asensio et al., 2013).

Mycovirus interactions that induce hypovirulence, such that between Hypovirus, an effective alternative biocontrol agent to conventional measures, with phytopathogenic fungi (Milgroom and Hillman, 2011), are among the most studied ones. As a result of viral infection, the virulence of the host phytopathogenic fungus is reduced or completely lost (Yu et al., 2010; Picarelli et al., 2017).

Extensive research on mycovirus infection in the filamentous fungus Cryphonectria parasitica laid the foundation for future studies on fungal hypovirulence or debilitation in other species (Ghabrial and Suzuki, 2009; Eusebio-Cope et al., 2015). The interactions of the mycovirus Cryphonectria hypovirus 1 (CHV1) with its fungal host Cryphonectria parasitica have been well studied and used as a reference in several studies on other pathogenic fungi, such as Fusarium graminearum (Chu et al., 2002), Sclerotinia homoeocarpa (Zhou and Boland, 1997), Botrytis cinerea (Wu et al., 2010), and Aspergillus spp. (Kotta-Loizou and Coutts, 2017).

Cryphonectria parasitica causes chestnut blight. This ascomycete infects the bark and cambium of chestnut trees through wounds and induces tumors on the bark, leading to the death of the distal parts by hardening the branches or trunk of the entire tree (Heiniger and Rigling, 1994). Two decades after the first record of the disease, it was observed that some infected trees began to heal, as indicated by the occurrence of non-lethal superficial tumors on the bark surface. This spontaneous recovery was a result of a mycovirus that infected Cryphonectria parasitica (Choi and Nuss, 1992; Robin and Heiniger, 2001).

CHV1 causes the hypovirulence of its fungal host. Its infection also inhibits the sexual reproduction of the fungus and reduces its pigmentation and sporulation, conferring a typical white appearance in vitro. The discovery of the transmissibility of hypovirulence provided the basis for chestnut blight biocontrol (Chen and Nuss, 1999; Nuss, 2005). In Europe, CHV1 strains are commercially available and have been proven successful in controlling chestnut blight (Nuss, 2005).

Interest in mycoviruses has increased in recent decades, and there has been a rapid progress in their study. First, this is associated with the fact that many mycoviruses lead to phenotypic changes in their host fungi, which is valuable for fundamental research and practical use. Next, the interest in these pathogens is also stimulated by technical advances in the field of mycovirus molecular biology. Finally, mycoviruses have been successfully used as tools to study host interactions and control mechanisms (Kyrychenko et al., 2018).

From an agricultural perspective, mycoviruses can contribute to sustainable agriculture as biological control agents. Currently, the control of phytopathogenic fungi is difficult because of the lack of adequate disease control strategies. In addition to their human health and environmental hazards, fungicides have other disadvantages. Therefore, there is an urgent need to develop innovative biocontrol measures to combat fungal diseases. In this context, the study of virus-host interactions is an important area of modern virology, in which mycoviruses can be used to explore the physiology of their fungal hosts (Ghabrial and Suzuki, 2009).

\section{Incidence of mycoviruses in Colletotrichum spp.}

Table 2 presents reports of mycovirus isolation from Colletotrichum spp. Studies in which the mycoviruses were not definitively classified into any currently known family are also included.

Rawlinson et al. (1975) recorded the presence of mycoviruses in 35 strains of Colletotrichum lindemuthianum isolated from beans and analyzed variations in their virulence. Characteristics such as morphology, growth rate, production and viability of conidia, and pathogenicity between the infected and uninfected fungi were examined. Only five fungi carried the virus, and none showed changes in the characteristics mentioned above (Tables 3 and 4).

The presence of mycoviruses has also been considered a criterion for comparing the races of the same pathogenic complex. Dale et al. (1988) confirmed that two groups, namely Type A and Type B, belonging to the Colletotrichum gloeosporioides complex caused anthracnose in Stylosanthes guyanensis. The presence of dsRNA virus particles was confirmed following the treatment of samples with DNase and S1 nuclease. Type A isolates presented two gel bands with different molecular weights, while Type B presented a greater variation in the number of bands and all were absent in Type A isolates (Table 5). However, the authors could not determine whether the presence of these particles affected fungal virulence, as evidenced in the case of CHV1 in Cryphonectria parasitica. Moreover, these two types may not be genetically compatible. Of note, however, vegetative incompatibility limits the transfer of viral particles, as non-recognition triggers programmed cell death (Wang et al., 2017).

There is not enough information to help completely elucidate the effects of viral infection on fungal physiology. It is difficult to obtain a virus-free isogenic strain for comparative studies between infected and non-infected isolates. Various methodologies have been used to obtain pure virus-free cultures, such as the supplementation of the culture medium with specific substances, such as cycloheximide (Campo et al., 2016) or ribavirin (Liu et al., 2019), which prevent viral replication. However, the appropriate dose of these substances must be determined such that they do not interfere with fungal metabolism (Lawana et al., 2014). Another method is successive samplings or the use of fungal conidia or spores that do not promote the vertical transmission of viral particles.

Jia et al. (2017) were the first to report a filamentous mycoviral particle in Colletotrichum camelliae. This fungus caused anthracnose in Camellia sinensis in China. Unfortunately, the virus could not be definitively classified into a specific family. Nonetheless, the name Colletotrichum camelliae filamentous virus 1 (CcFV-1) was assigned. To obtain virus-free isogenic strains, the fungus was grown on potato dextrose agar (PDA) at $25^{\circ} \mathrm{C}$ under a 24-hour photoperiod for 1 month. The mycelium, growth rate, morphology, and ability to cause leaf damage of the obtained strains were observed. Colonies of the mycovirus-free pathogens exhibited hyphal rings, 
Table 2. Mycoviruses infecting Colletotrichum spp.

\begin{tabular}{|c|c|c|c|c|c|}
\hline Host & Mycovirus & Nucleic acid & Family & Genome size & Reference \\
\hline C. lindemuthianum & - & dsRNA & - & - & $\begin{array}{l}\text { Rawlinson et al. } \\
\text { (1975) }\end{array}$ \\
\hline C. gloeosporioides & - & dsRNA & - & - & Dale et al. (1988) \\
\hline \multirow[t]{2}{*}{ C. acutatum Coll-365 } & - & dsRNA & - & RNA1 - $1.3 \mathrm{~kb}$ & Liao et al. (2012) \\
\hline & & & & RNA2 - $2.5 \mathrm{~kb}$ & \\
\hline \multirow[t]{2}{*}{ C. acutatum Coll-524 } & - & dsRNA & - & RNA1 - $1.4 \mathrm{~kb}$ & Liao et al. (2012) \\
\hline & & & & RNA2 - $1.7 \mathrm{~kb}$ & \\
\hline C. gloeosporioides & - & dsRNA & - & - & $\begin{array}{l}\text { Figueirêdo et al. } \\
\text { (2012) }\end{array}$ \\
\hline C. gloeosporioides & - & dsRNA & - & $3 \mathrm{~kb}$ & Lima et al. (2012) \\
\hline C. acutatum & $\begin{array}{l}\text { Colletotrichum } \\
\text { acutatum partitivirus } \\
1 \text { (CaPV1) }\end{array}$ & dsRNA & Partitiviridae & - & Zhong et al. (2014) \\
\hline Colletotrichum sp. & - & dsRNA & - & - & Bezerra (2015) \\
\hline \multirow[t]{2}{*}{ C. truncatum } & \multirow{2}{*}{$\begin{array}{l}\text { Colletotrichum } \\
\text { truncatum } \\
\text { partitivirus 1 RNA1 } \\
\text { (CtParV1) }\end{array}$} & \multirow[t]{2}{*}{ dsRNA } & \multirow[t]{2}{*}{ Partitiviridae } & RNA1 - $1.8 \mathrm{~kb}$ & \multirow{2}{*}{$\begin{array}{l}\text { Marzano et al. } \\
\text { (2016) }\end{array}$} \\
\hline & & & & RNA2 - $1.5 \mathrm{~kb}$ & \\
\hline \multirow{2}{*}{$\begin{array}{l}\text { Colletotrichum sp. } \\
\text { CNPUV } 378\end{array}$} & \multirow[t]{2}{*}{-} & \multirow[t]{2}{*}{ dsRNA } & \multirow[t]{2}{*}{ Partitiviridae } & RNA1 - $1.5 \mathrm{~kb}$ & \multirow{2}{*}{$\begin{array}{l}\text { Rosseto et al. } \\
(2016)\end{array}$} \\
\hline & & & & RNA2 - $2.5 \mathrm{~kb}$ & \\
\hline \multirow[t]{3}{*}{ C. gloeosporioides } & \multirow{3}{*}{$\begin{array}{l}\text { Colletotrichum } \\
\text { gloeosprioides } \\
\text { chrysovirus } 1 \text { (CgCV1) }\end{array}$} & \multirow[t]{3}{*}{ dsRNA } & \multirow[t]{3}{*}{ Chrysoviridae } & RNA1 - $3.3 \mathrm{~kb}$ & \multirow[t]{3}{*}{ Zhong et al. (2016) } \\
\hline & & & & RNA2 - $2.8 \mathrm{~kb}$ & \\
\hline & & & & RNA3 - $2.6 \mathrm{~kb}$ & \\
\hline C. higginsianum & $\begin{array}{l}\text { Colletotrichum } \\
\text { higginsianum non- } \\
\text { segmented dsRNA } \\
\text { virus } 1 \text { (ChNRV1) }\end{array}$ & dsRNA & Partitiviridae & - & $\begin{array}{l}\text { Campo et al. } \\
\text { (2016), Olivé \& } \\
\text { Campo (2021) }\end{array}$ \\
\hline \multirow[t]{8}{*}{ C. camelliae } & \multirow{8}{*}{$\begin{array}{l}\text { Colletotrichum } \\
\text { camelliae filamentous } \\
\text { virus } 1(\mathrm{CcFV}-1)\end{array}$} & \multirow[t]{8}{*}{ dsRNA } & \multirow[t]{8}{*}{-} & RNA1 - $2.4 \mathrm{~kb}$ & \multirow[t]{8}{*}{ Jia et al. (2017) } \\
\hline & & & & RNA2 - $2.2 \mathrm{~kb}$ & \\
\hline & & & & RNA3 - $2.0 \mathrm{~kb}$ & \\
\hline & & & & RNA4 - $1.2 \mathrm{~kb}$ & \\
\hline & & & & RNA5 - $1.1 \mathrm{~kb}$ & \\
\hline & & & & RNA6 - $1.0 \mathrm{~kb}$ & \\
\hline & & & & RNA7 - 1,0 kb & \\
\hline & & & & RNA8 - $0.9 \mathrm{~kb}$ & \\
\hline \multirow[t]{7}{*}{ C. fructicola } & \multirow{7}{*}{$\begin{array}{l}\text { Colletotrichum } \\
\text { fructicola chrysovirus } \\
1(\mathrm{CfCV} 1)\end{array}$} & \multirow[t]{7}{*}{ dsRNA } & \multirow[t]{7}{*}{ Chrysoviridae } & RNA1 - $3.6 \mathrm{~kb}$ & \multirow[t]{7}{*}{ Zhai et al. (2018) } \\
\hline & & & & RNA2 - $2.8 \mathrm{~kb}$ & \\
\hline & & & & RNA3 - $2.6 \mathrm{~kb}$ & \\
\hline & & & & RNA4 - $2.4 \mathrm{~kb}$ & \\
\hline & & & & RNA5 - $1.7 \mathrm{~kb}$ & \\
\hline & & & & RNA6 - $1.5 \mathrm{~kb}$ & \\
\hline & & & & RNA7 - $1.2 \mathrm{~kb}$ & \\
\hline C. gloeosporioides & $\begin{array}{l}\text { Colletotrichum } \\
\text { gloeosporioides RNA } \\
\text { virus } 1 \text { (CgRV1) }\end{array}$ & dsRNA & Partitiviridae & $2.9 \mathrm{~kb}$ & Wang et al. (2019) \\
\hline C. gloeosporioides & $\begin{array}{l}\text { Colletotrichum } \\
\text { gloeosporioides } \\
\text { ourmia-like virus } 1 \\
\text { (CgOLV1) }\end{array}$ & $(+)$ ssRNA & - & $2.51 \mathrm{~kb}$ & Guo et al. (2019) \\
\hline
\end{tabular}


Table 3. Colony characteristics of $\alpha$ isolates with and without virus on Mathur's medium.

\begin{tabular}{|c|c|c|c|c|}
\hline Isolate (source)* & Color & Aerial mycelium & Spores & Growth rate $\left(\mathrm{mm}^{\left.- \text {day }^{-1}\right)}\right.$ \\
\hline \multicolumn{5}{|l|}{ With virus } \\
\hline$\alpha 10(B)$ & Hyaline pink & - & +++ & $4.5 \pm 0.2$ \\
\hline$\alpha 229(\mathrm{~W})$ & Pale buff & - & +++ & $4.1 \pm 0.2$ \\
\hline$\alpha 4(\mathrm{H})$ & Dark buff & ++ & ++ & $5.4 \pm 0.04$ \\
\hline$\alpha 5(\mathrm{~W})$ & Dark buff & - & + & $5.2 \pm 0.4$ \\
\hline \multicolumn{5}{|l|}{ Without virus } \\
\hline$\alpha 9(\mathrm{H})$ & Dark brown & ++ & +++ & $4.2 \pm 0.1$ \\
\hline$\alpha 1(\mathrm{H})$ & Dark brown & + & ++ & $4.7 \pm 0.09$ \\
\hline$\alpha 1(\mathrm{~B})$ & Hyaline pink & - & ++ & $3.8 \pm 0.06$ \\
\hline$\alpha 2(\mathrm{H})$ & Gray buff & ++ & + & $3.9 \pm 0.08$ \\
\hline
\end{tabular}

*B = Bannerot, INRA, Versailles; W = Wharton, Unilever Research Laboratory, Bedford; H = Hubbeling, IPO, Wageningen. Adapted from Rawlinson et al. (1975).

Table 4. Pathogenicity of isolates with and without virus against susceptible hosts.

\begin{tabular}{ccccccccc}
\hline \multicolumn{4}{c}{ With virus } & \multicolumn{3}{c}{ Without virus } & Control \\
\hline$\alpha 10(\mathrm{~B})$ & $\alpha 229(\mathrm{~W})$ & $\alpha 4(\mathrm{H})$ & $\alpha 5(\mathrm{~W})$ & $\alpha 9(\mathrm{H})$ & $\alpha 1(\mathrm{H})$ & $\alpha 1(\mathrm{~B})$ & $\alpha 2(\mathrm{H})$ \\
$\mathbf{0 . 8 3}$ & 0.32 & 0.66 & 0.78 & 0.96 & 0.29 & 0.30 & 1.14 & 5.0 \\
\hline
\end{tabular}

Mean scores for 360 'Processor' and 'Michelite' seedlings were rated on a scale of 0 (immunity) to 5 (general infection; dead plants) S.E.D. $=0.277$. Adapted from Rawlinson et al. (1975).

Table 5. Presence of major dsRNA bands in isolates of Colletotrichum gloeosporioides from Stylosanthes.

\begin{tabular}{|c|c|c|c|c|c|c|c|c|c|}
\hline \multirow{2}{*}{ Band } & \multirow{2}{*}{$\begin{array}{c}M_{r}(\times \\
\left.10^{-6}\right)\end{array}$} & \multicolumn{7}{|c|}{ Type B isolates } & \multirow{2}{*}{$\begin{array}{l}\text { Type A } \\
\text { isolates }\end{array}$} \\
\hline & & B1 & B2 & B3 & B4 & B5 & B6 & B7 & \\
\hline $\mathrm{a}$ & 2.0 & - & - & +++ & - & - & - & + & - \\
\hline b & 1.8 & - & - & - & - & - & - & - & + \\
\hline c & 1.6 & - & - & - & - & - & - & - & ++ \\
\hline d & 1.5 & ++ & + & - & + & + & ++ & + & - \\
\hline e & 1.4 & ++ & + & - & + & ++ & ++ & + & - \\
\hline $\mathrm{f}$ & 1.1 & +++ & ++ & + & ++ & ++ & ++ & ++ & - \\
\hline g & 0.8 & +++ & +++ & + & ++ & ++ & +++ & ++ & - \\
\hline $\mathrm{h}$ & 0.5 & +++ & ++ & + & ++ & ++ & + & ++ & - \\
\hline $\mathrm{i}$ & 0.3 & + & - & - & - & - & + & - & - \\
\hline $\mathrm{j}$ & 0.2 & + & - & - & - & - & - & - & - \\
\hline
\end{tabular}

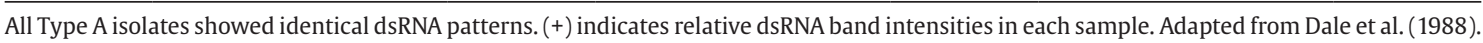

reduced black colony pigmentation, and increased mycelial growth rate. However, contrary to most reports, CcFV-1 did not cause hypovirulence. Even when the fungus was cured, it presented with the characteristic disease symptoms. In addition to interfering with mycelial growth, abnormalities in cell content were also found, such as the presence of viral vesicles and a reduction in the number of vacuoles and Woronin bodies. Some hypotheses can be made to explain how mycoviruses interfere with fungal metabolism and cause changes in the host phenotype.
The first hypothesis is that the virus interferes with the expression of genes involved in cell proliferation. Applen Clancey et al. (2020) reported that mycovirus infection in Malassezia sympodialis resulted in reduced expression of genes related to metabolic processes, such as reduced oxidation, transmembrane transport, cell cycle, and cell division. Another hypothesis is that the influence on the growth and reproduction of the fungus is directly linked to the number of viral particles. Okada et al. (2018) studied the consequences of infection by Alternaria alternata 
chrysovirus 1 in A. alternata-associated cellular damage to the high titers of these viral particles. The isolates that exhibited impaired mycelial growth and unregulated pigmentation contained higher amounts of particles. They originally postulated that isolates with a normal phenotype were free of virus. However, subsequent screening via RTPCR demonstrated the continuous presence of a dsRNA molecule, indicating that these isolates were infected but corresponded to strains with low viral titers.

Upon infection by two different viruses, Colletotrichum acutatum showed increased activity of laccase (Liao et al., 2012), an important enzyme for colonization. However, a high rate of fungal colonization is reportedly associated with the genotype of the host plant.

In a study of the morphological identification of 39 fungi classified as Colletotrichum, Lima et al. (2012) verified the presence of dsRNA in three isolates. This was the first record of mycoviruses in C. gloeosporioides. Simultaneously, Figueirêdo et al. (2012) found that C. gloeosporioides caused anthracnose in cashew trees and identified characteristic dsRNA bands. Transmission electron microscopy revealed trace amounts of isometric particles characteristic to viruses belonging to the Chrysoviridae, Partitiviridae, and Totiviridae families.

Guo et al. (2019) isolated a novel mycovirus from $C$. gloeosporioides, a cotton pathogen in China. This virus with a 2,516-nucleotide genome was named $\mathrm{C}$. gloeosporioides ourmia-like virus 1 (CgOLV1). Based on phylogenetic analysis, this virus was placed in the mycovirus clade whose members were related to the genus Ourmiavirus.

\section{Chrysoviridae family}

The Chrysoviridae family comprises isometric, nonenveloped viruses with segmented and linear dsRNA genomes. They have three to seven genomic segments, each of which is individually encapsulated. Chrysoviruses infect fungi, plants, and possibly insects and can cause hypovirulence in their fungal hosts. They have no known vectors and do not have an extracellular phase in their replication cycle. They are transmitted intracellularly during hyphal growth, via asexual or sexual spores, or through hyphal anastomosis (Kotta-Loizou et al., 2020).

Zhai et al. (2018) characterized the virus infecting Colletotrichum fructicola and examined its effects on fungal growth rate, colony morphology, and virulence in detached pear (Pyrus bretschneideri) fruits. This heptasegmented dsRNA-type virus was named C. fructicola chrysovirus 1 (CfCV1). CfCV1 reduced the fungal growth rate and virulence (Figure 1) but did not substantially alter colony morphology. Vertical (sexual spores) and horizontal (hyphae anastomosis) transfer of the virus was also confirmed. The transfer rate of mycoviruses through sexual and asexual reproduction can vary from one host to another and between viral families. For some authors, this has been the reason why some strategies such as the biological control of some fungal diseases are not effective (Hillman and Suzuki, 2004; García-Pedrajas et al., 2019). Unlike what was observed by Zhai et al. (2018) in C. fructicola, Hillman and Suzuki (2004) found no evidence of mycoviruses in the ascospores of $C$. parasitica. Another interesting fact is that co-infection by different mycoviruses in the same host significantly impacts the efficiency of vertical transmission, with a decline after subsequent cultures (Aulia et al., 2019). Lee et al. (2014) analyzed the conidial transmission rates of four isolated $F$. graminearum PH1 viruses from different viral families. The study revealed that two mycoviruses that induced hypovirulence and changes in the host phenotype were transmitted more efficiently than those that caused asymptomatic infections. For the authors, this high transmissibility suggests
A

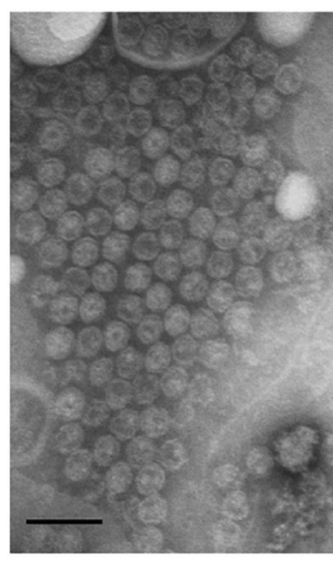

B

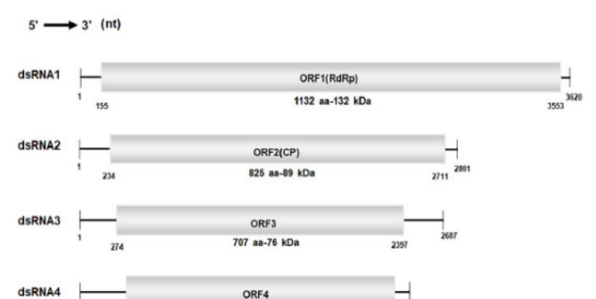

ASRNA4
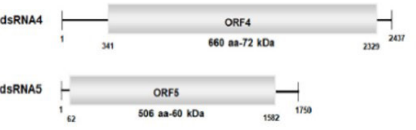

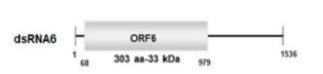

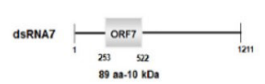

C

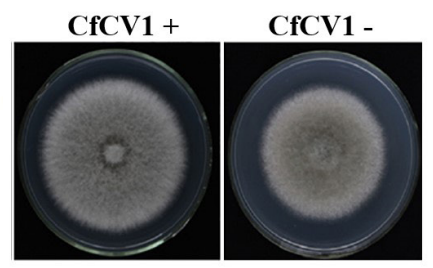

D

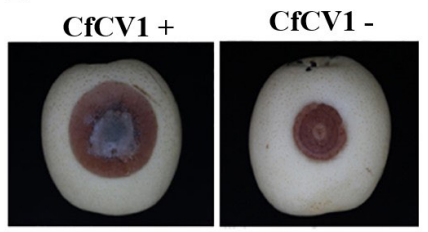

Figure 1. (A) Transmission electron micrographs of virus-like particles (VLPs); (B) Genomic organization of dsRNA1-7 of CfCV1; (C) Colony morphology in PDA medium $\left(25^{\circ} \mathrm{C}, 4\right.$ days); (D) Pear fruits wound-inoculated with colonized plugs of tested strains and photographed at 6 days post inoculation (2016). CfCV1 +: with virus; CfCV1 -: without virus. This image is a copyright of Zhai et al. (2018). 
that hypovirulent mycoviruses are better adapted to $F$. graminearum $\mathrm{PH} 1$ than non-hypovirulent mycoviruses.

Zhong et al. (2016) isolated a new virus belonging to the Chrysoviridae family from C. gloeosporioides. This virus was named C. gloeosporioides chrysovirus 1 (CgCV1), but unlike that of CfCV1, its genome had only three segments. However, the authors did not evaluate the effects of the presence of CgCV1 on C. gloeosporioides physiology.

\section{Partitiviridae family}

The Partitiviridae family comprises small, isometric, non-enveloped viruses with bisegmented double-stranded (ds) RNA genomes of 3-4.8 kbp. The two segments of the genome are individually encapsulated. The family includes five genera, each with specific hosts: plants or fungi for the genera Alphapartitivirus and Betapartitivirus, fungi for the genus Gammapartitivirus, plants for the genus Deltapartitivirus, and protozoa of the genus Cryspovirus. Partitiviruses are transmitted intracellularly through seeds in plants; oocysts in protozoa; and hyphal anastomosis, cell division, and sporogenesis in fungi. There are no known natural vectors (Vainio et al., 2018). Most partitiviruses infecting Colletotrichum have already been characterized.

Rosseto et al. (2016) studies 26 Colletotrichum species isolated from different hosts and found that only one of them showed signs of mycovirus infection. Following treatment with DNAse and S1 nuclease, gel bands were visualized and matched to a mycovirus. The structural characteristics observed in transmission electron microscopy suggested that the mycovirus belonged to the family Partitiviridae.

Marzano et al. (2016) isolated a bisegmented mycovirus belonging to the Partitiviridae family, called Colletotrichum partitivirus 1 (Ct-ParV1), from Colletotrichum truncatum. This fungus causes anthracnose in several crops, particularly soybean, in which it is transmitted via contaminated seeds (Goulart, 2009).

Zhong et al. (2014) analyzed the fungus C. acutatum isolated from anthracnotic lesions in pepper and verified the presence of the virus $C$. acutatum partitivirus 1 (CaPV1). CaPV1 infection increased conidia production. However, there were no significant differences in the mycelial growth rate between the infected and cured isogenic strains (Figure 2).

Campo et al. (2016) analyzed RNA silencing in Colletotrichum higginsianum and found that when this mechanism failed, the mycovirus decreased conidia production and altered their size. In other words, $C$. higginsianum employs RNA silencing as an antiviral mechanism to suppress the virus and its debilitating effects. RNA silencing is an antiviral defense mechanism found in fungi, plants, and animals. In contrast, suppression of this mechanism is one of the strategies employed by viruses to neutralize the antiviral arsenal of hosts (Aulia et al., 2021). The ability of mycoviruses to suppress the defenses of fungi can guarantee the complete establishment of the infection and the possibility of intra- and interspecific transmission. Despite being an important mechanism in the interaction between host viruses, only a limited
A

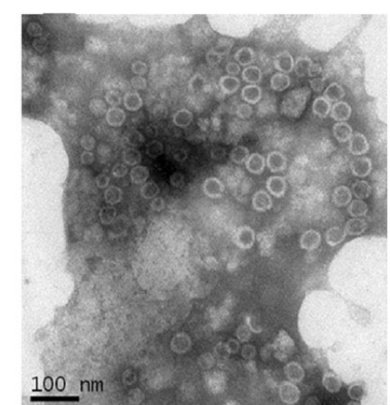

C

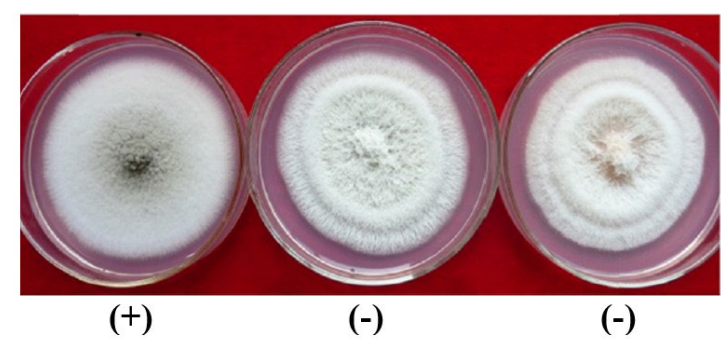

B

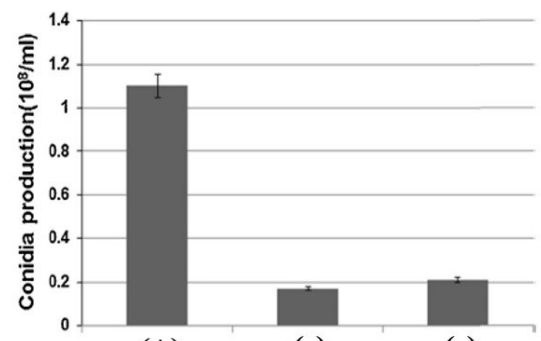

$(+)$

$(-)$

$(-)$

D

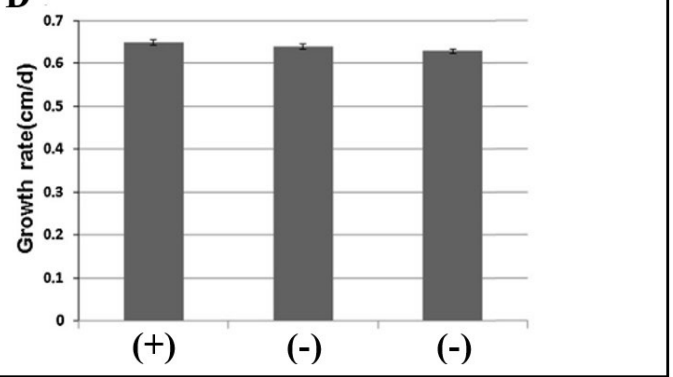

Figure 2. (A) Transmission electron micrograph of the virus particles in Colletotrichum acutatum strain HNZJ001; (B) Comparison of conidia production among HNZJ001 (with virus), HNZJ001-E3 (without virus), and HNZJ001-E4 (without virus); (C) Colony morphology of HNZJ001, HNZJ001-E3, and HNZJ001-E4 after culture on PDA for 10 days; (D) Comparison of mycelial growth rate among HNZJ001, HNZJ001-E3, and HNZJ001-E4. (+) with virus; (-) without virus. This image is a copyright of Zhong et al. (2014). 


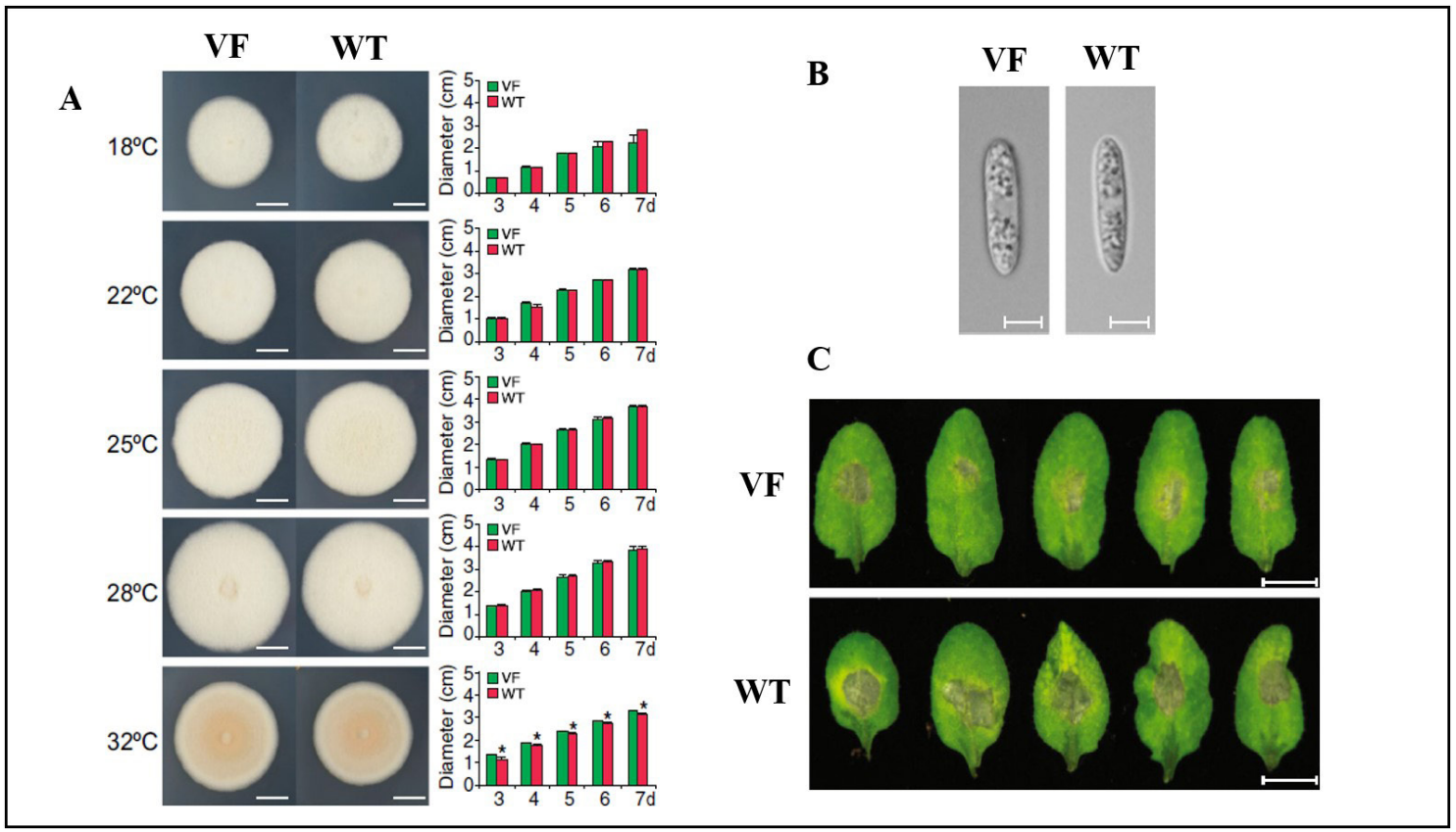

Figure 3. (A) Colony morphology (left panels) and growth rate (right panels) of the virus-free (VF) and ChNRV1-infected wild-type (WT) Colletotrichum higginsianum isolates under different temperatures; (B) Confocal images of VF and WT Colletotrichum higginsianum conidia; (C) Dissected leaves of Arabidopsis Col-0 whole plants infected with Colletotrichum higginsianum without (VF) or with (WT) the virus. This image is copyright of Olivé and Campo (2021).

number of RNA silencing suppressors have been identified in mycoviruses. These include the p29 protein of CHV1, p.32 protein of Rosellinia necatrix mycoreovirus 3, and pORF2 protein of F. graminearum virus 1 (Segers et al., 2006; Yaegashi et al., 2013; Yu et al., 2020).

C. higginsianum strain IMI349063A is naturally infected with the dsRNA virus $C$. higginsianum nonsegmented dsRNA virus 1 (ChNRV1). Olivé and Campo (2021) investigated the biological effects of the presence of ChNRV1 in C. higginsianum by comparing the strains with and without the virus. They analyzed the production and morphology of conidia, pathogenicity in Arabidopsis, vegetative growth on Mathur's medium and PDA, and vegetative growth under specific conditions of osmotic and thermal stress. The presence of ChNRV1 did not interfere with conidiogenesis; however, the formed conidia were narrower (Figure 3). Moreover, ChNRV1 slightly increased the virulence of $C$. higginsianum (hypervirulence) infecting Arabidopsis. ChNRV1 did not affect the vegetative growth of $C$. higginsianum under osmotic stress; however, it suppressed fungal growth under thermal stress, and this effect was more evident in the carrier strain. These findings indicate that although ChNRV1 did not impair the growth and conidiogenesis of fungi, it could cause hypervirulence of the fungal host. Hypervirulence is characterized by an increased ability of a phytopathogen to cause a particular disease. This phenomenon is usually associated with sporulation, vegetative growth, and the ability to cause superior injuries compared to the isogenic strain (Tran et al., 2019). Although hypervirulence is common, some characteristics observed in C. higginsianum were also present in other phytopathogens, such as Phytophthora infestans, Nectria radicicola, Aspergillus fumigatus, and Leptosphaeria biglobosa (Cai and Hillman, 2013; Ahn and Lee, 2001; Özkan and Coutts, 2015; Shah et al., 2020). More in-depth studies are needed to unravel the interference mechanisms used by mycoviruses that enhance the pathogenicity to their hosts.

Wang et al.(2019) confirmed the presence of a mycovirus in C. gloeosporioides, a foliar pathogen of Citrus in China. This bisegmented virus with a 2975 bp dsRNA genome was named C. gloeosporioides RNA virus 1 (CgRV1). However, the authors did not evaluate the effects of CgCV1 on $C$. gloeosporioides physiology.

\section{Conclusions and future perspectives}

The impact of mycovirus infection on Colletotrichum spp. Has not yet been thoroughly explored, considering the importance of this fungus as a phytopathogen in different cultures worldwide.

The phenomenon of hypovirulence, extensively studied in the fungus $C$. parasitica, is an interesting strategy when considering the biological control of fungal diseases. The discovery that some mycoviruses can have the same impact on pathogenic species of Colletotrichum led to the elucidation of the molecular mechanisms of this interaction, especially the effects of infection on the fungal host. One possible way to understand this process is RNA silencing. This antiviral defense mechanism found in fungi, plants, and animals can be suppressed as a strategy used 
by mycoviruses to neutralize the antiviral arsenal of the hosts, as observed in C. higginsianum.

As observed in other phytopathogens, the mycoviruses already characterized in Colletotrichum have a dsRNA genome and belong to the Partitiviridae family. However, the taxonomic classification of majority of cases remains unclear. Further studies are needed for the deeper understanding of mycoviruses already detected in phytopathogenic species, aiming at the biological control of these diseases. It is also necessary to understand how these infected fungi establish themselves in the environment and whether this viral infection can be used from an agronomic point of view.

\section{Acknowledgements}

This study was financed by the Coordination for the Improvement of Higher Education Personnel (CAPES), Brazil, (financing Code 001) and the Foundation of Research Support of Amazonas State (FAPEAM 002/2018 - UNIVERSAL AMAZONAS). We also thank Editage (www.editage.com) for English language editing.

\section{References}

AHN, I.P. and LEE, Y.H., 2001. A viral double-stranded RNA up regulates the fungal virulence of Nectria radicicola. Molecular Plant-Microbe Interactions, vol. 14, no. 4, pp. 496-507. http:// dx.doi.org/10.1094/MPMI.2001.14.4.496. PMid:11310737.

ANAGNOSTAKIS, S.L. and DAY, P.R., 1979. Hypovirulence conversion in Endothia parasitica. Phytopathology, vol. 69, no. 12, pp. 12261229. http://dx.doi.org/10.1094/Phyto-69-1226.

APPLEN CLANCEY, S., RUCHTI, F., LEIBUNDGUT-LANDMANN, S., HEITMAN, J. and IANIRI, G., 2020. A novel mycovirus evokes transcriptional rewiring in the fungus Malassezia and stimulates beta interferon production in macrophages. mBio, vol. 11, no. 5, pp. 1-18. http://dx.doi.org/10.1128/mBio.01534-20. PMid:32873760.

AULIA, A., ANDIKA, I.B., KONDO, H., HILLMAN, B.I. and SUZUKI, N., 2019. A symptomless hypovirus, CHV4, facilitates stable infection of the chestnut blight fungus by a coinfecting reovirus likely through suppression of antiviral RNA silencing. Virology, vol. 533, pp. 99-107. http://dx.doi.org/10.1016/j.virol.2019.05.004. PMid:31146252.

AULIA, A., HYODO, K., HISANO, S., KONDO, H., HILLMAN, B.I. and SUZUKI, N., 2021. Identification of an RNA silencing suppressor encoded by a symptomless fungal hypovirus, Cryphonectria Hypovirus 4. Biology (Basel), vol. 10, no. 2, pp. 100. http://dx.doi. org/10.3390/biology10020100. PMid:33572564.

BAILEY, J.A. and JEGER, M.J., 1992. Colletotrichum: biology, pathology and control. Wallingford: $\mathrm{CAB}$ International.

BANKS, G.T., BUCK, K.W., CHAIN, E.B., HIMMELWEIT, F., MARKS, J.E., TYLER, J.M., HOLLINGS, M., LAST, F.T. and STONE, O.M., 1968. Viruses in fungi and interferon stimulation. Nature, vol. 218, no. 5141, pp. 542-545. http://dx.doi.org/10.1038/218542a0. PMid:4967851.

BEZERRA, T.E., 2015. Potencial biotecnológico dos fungos endofiticos do guaraná (Paullinia cupana var. sorbilis) no controle biológico da antracnose. Manaus: Universidade Federal do Amazonas, 101 p. Tese de doutorado em Biotecnologia.
BUCK, K.W., 1988. From interferon induction to fungal viruses. European Journal of Epidemiology, vol. 4, no. 4, pp. 395-399. http://dx.doi.org/10.1007/BF00146388. PMid:2462507.

CAI, G. and HILLMAN, B.I., 2013. Phytophthora viruses. Advances in Virus Research, vol. 86, pp. 327-350. http://dx.doi.org/10.1016/ B978-0-12-394315-6.00012-X. PMid:23498912.

CAMPO, S., GILBERT, K.B. and CARRINGTON, J.C., 2016. Small RNA-Based antiviral defense in the phytopathogenic fungus Colletotrichum higginsianum. PLoS Pathogens, vol. 12, no. 6, pp. e1005640. http://dx.doi.org/10.1371/journal.ppat.1005640. PMid:27253323.

CAO, C., LI, H., JONES, M.G.K. and WYLIE, S.J., 2019. Challenges to elucidating how endornaviruses influence fungal hosts: creating mycovirus-free isogenic fungal lines and testing them. Journal of Virological Methods, vol. 274, pp. 113745. http://dx.doi. org/10.1016/j.jviromet.2019.113745. PMid:31563584.

CHEN, B. and NUSS, D.L., 1999. Infectious cDNA clone of hypovirus CHV1-Euro7: a comparative virology approach to investigate virus-mediated hypovirulence of the chestnut blight fungus Cryphonectria parasitica. Journal of Virology, vol. 73, no. 2, pp. 985-992. http://dx.doi.org/10.1128/JVI.73.2.985-992.1999. PMid:9882299.

CHOI, G.H. and NUSS, D.L., 1992. Hypovirulence of chestnut blight fungus conferred by an infectious viral cDNA. Science, vol. 257, no. 5071, pp. 800-803. http://dx.doi.org/10.1126/science.1496400. PMid:1496400.

CHU, Y.M., JEON, J., YEA, S., KIM, Y., YUN, S., LEE, Y. and KIM, K., 2002. Double-stranded RNA mycovirus from Fusarium graminearum. Applied and Environmental Microbiology, vol. 68, no. 5, pp. 25292534. http://dx.doi.org/10.1128/AEM.68.5.2529-2534.2002. PMid:11976130.

DALE, J.L., MANNERS, J.M. and IRWIN, J.A.G., 1988. Colletotrichum gloeosporioides isolates causing different anthracnose diseases on Stylosanthes in Australia carry distinct double-stranded RNAs. Transactions of the British Mycological Society, vol. 91, no. 4, pp. 671-676. http://dx.doi.org/10.1016/S0007-1536(88)80043-3.

DOWLING, M., PERES, N., VILLANI, S. and SCHNABEL, G., 2020. Managing Colletotrichum on fruit crops: a "complex" challenge. Plant Disease, vol. 104, no. 9, pp. 2301-2316. http://dx.doi. org/10.1094/PDIS-11-19-2378-FE. PMid:32689886.

EUSEBIO-COPE, A., SUN, L., TANAKA, T., CHIBA, S., KASAHARA, S. and SUZUKI, N., 2015. The chestnut blight fungus for studies on virus/host and virus/virus interactions: from a natural to a model host. Virology, vol. 477, pp. 164-175. http://dx.doi. org/10.1016/j.virol.2014.09.024. PMid:25454384.

FIGUEIRÊDO, L.C., FIGUEIRÊDO, G.S., GIANCOLI, Á.C.H., TANAKA, F.A.O., SILVA, L.A.O., KITAJIMA, E.W., A. FILHO, S. and AZEVEDO, J.L., 2012. Detection of isometric, dsRNA-containing viral particles in Colletotrichum gloeosporioides isolated from cashew tree. Tropical Plant Pathology, vol. 37, no. 2, pp. 142-145. http:// dx.doi.org/10.1590/S1982-56762012000200007.

GARCÍA-PEDRAJAS, M.D., CAÑIZARES, M.C., SARMIENTO-VILLAMIL, J.L., JACQUAT, A.G., and DAMBOLENA, J.S., 2019. Mycoviruses in biological control: from basic research to field implementation. Phytopathology, vol. 109, pp. 1828-1839. https://doi.org/10.1094/ PHYTO-05-19-0166-RVW.

GHABRIAL, S.A. and SUZUKI, N., 2009. Viruses of plant pathogenic fungi. Annual Review of Phytopathology, vol. 47, no. 1, pp. 353384. http://dx.doi.org/10.1146/annurev-phyto-080508-081932. PMid:19400634.

GHABRIAL, S.A., CASTÓN, J.R., JIANG, D., NIBERT, M.L. and SUZUKI, N., 2015. 50-plus years of fungal viroses. Virology, vol. 479-480, 
pp. 356-368. http://dx.doi.org/10.1016/j.virol.2015.02.034. PMid:25771805.

GOULART, A.C.P., 2009. Detecção e controle químico de Colletotrichum em sementes de soja e algodão. Empresa Brasileira de Pesquisa Agropecuária, vol. 100, pp. 1-33.

GUO, J., ZHU, J.Z., ZHOU, X.Y., ZHONG, J., LI, C.H., ZHANG, Z.G. and ZHU, H.J., 2019. A novel ourmia-like mycovirus isolated from the plant pathogenic fungus Colletotrichum gloeosporioides. Archives of Virology, vol. 164, no. 10, pp. 2631-2635. http:// dx.doi.org/10.1007/s00705-019-04346-2. PMid:31367950.

HEINIGER, U. and RIGLING, D., 1994. Biological control of chestnut blight in Europe. Annual Review of Phytopathology, vol. 32, no. 1, pp. 581-599. http://dx.doi.org/10.1146/annurev. py.32.090194.003053.

HERRERO ASENSIO, N., SÁNCHEZ MÁRQUEZ, S. and ZABALGOGEAZCOA, I., 2013. Mycovirus effect on the endophytic establishment of the entomopathogenic fungus Tolypocladium cylindrosporum in tomato and bean plants. BioControl, vol. 58, no. 2, pp. 225-232. http://dx.doi.org/10.1007/s10526-012-9476-9.

HILLMAN, B.I. and SUZUKI, N., 2004. Viruses of the chestnut blight fungus, Cryphonectria parasitica. Advances in Virus Research, vol. 63, pp. 423-472. http://dx.doi.org/10.1016/S00653527(04)63007-7. PMid:15530566.

HOLLINGS, M., 1962. Viruses associated with a die-back disease of cultivated mushroom. Nature, vol. 196, no. 4858, pp. 962-965. http://dx.doi.org/10.1038/196962a0.

HYDE, K.D., CAI, L., CANNON, P.F., CROUCH, J.A., CROUS, P.W., DAMM, U., GOODWIN, P.H., CHEN, H., JOHNSTON, P.R., JONES, E.B.G., LIU, Z.Y., MCKENZIE, E.H.C., MORIWAKI, J., NOIREUNG, P., PENNYCOOK, S.R., PFENNING, L.H., PRIHASTUTI, H., SATO, T., SHIVAS, R.G., TAN, Y.P., TAYLOR, P.W.J., WEIR, B.S., YANG, Y.L. and ZHANG, J.Z., 2009. [viewed 21 February 2021]. Colletotrichum - names in current use. Fungal Diversity [online], vol. 39, pp. 147-183. Available from: http://www.fungaldiversity.org/fdp/ sfdp/FD39-7.pdf

International Committee on Taxonomy Viruses - ICTV, 2020 [viewed 23 October 2020]. The 10th Report of the ICTV [online]. Available from: https://talk.ictvonline.org/ictv-reports/ ictv_online_report/.

JIA, H., DONG, K., ZHOU, L., WANG, G., HONG, N., JIANG, D. and XU, W., 2017. A dsRNA virus with filamentous viral particles. Nature Communications, vol. 8, no. 1, pp. 168. http://dx.doi. org/10.1038/s41467-017-00237-9. PMid:28761042.

KOTTA-LOIZOU, I. and COUTTS, R.H.A., 2017. Mycoviruses in Aspergilli: a comprehensive review. Frontiers in Microbiology, vol. 8, pp. 1699. http://dx.doi.org/10.3389/fmicb.2017.01699. PMid:28932216.

KOTTA-LOIZOU, I., CASTÓN, J.R., COUTTS, R.H.A., HILLMAN, B.I., JIANG, D., KIM, D., MORIYAMA, H., SUZUKI, N., and the ICTV REPORT CONSORTIUM, 2020. ICTV Virus Taxonomy Profile: chrysoviridae. The Journal of General Virology, vol. 101, no. 2, pp. 143-144. http:// dx.doi.org/10.1099/jgv.0.001383. PMid:31958044.

KYRYCHENKO, A.N., TSYGANENKO, K.S. and OLISHEVSKA, S.V., 2018. Hypovirulence of mycoviruses as a tool for biotechnological control of phytopathogenic fungi. Cytology and Genetics, vol. 52, no. 5, pp. 374-384. http://dx.doi.org/10.3103/ S0095452718050043.

LAWANA, V., KORRAPATI, M.C. and MEHENDALE, H.M., 2014. Cycloheximide. In: P. WEXLER, ed. Encyclopedia of Toxicology. 3rd ed. London: Academic Press, pp. 1103-1105.

LECOQ, H., BOISSONNET-MENES, M. and DELHOTAL, P., 1979. Infectivity and transmission of fungal viruses. In: H.P. MOLITORIS, M. HOLLINGS, H.A WOOD, eds. Fungal viruses.
Berlin: Springer-Verlag, pp. 34-47. http://dx.doi.org/10.1007/9783-642-67373-3_4.

LEE, K.M., CHO, W.K., YU, J., SON, M., CHOI, H., MIN, K., LEE, Y.W. and KIM, K.H., 2014. A comparison of transcriptional patterns and mycological phenotypes following infection of Fusarium graminearum by four mycoviruses. PLoS One, vol. 9, no. 6, pp. e100989. http://dx.doi.org/10.1371/journal.pone.0100989. PMid:24964178.

LEFKOWITZ, E.J., DEMPSEY, D.M., HENDRICKSON, R.C., ORTON, R.J., SIDDELL, S.J. and SMITH, D.B., 2018. Virus taxonomy: the database of the International Committee on Taxonomy of Viruses (ICTV). Nucleic Acids Research, vol. 46, no. D1, pp. D708-D717. http:// dx.doi.org/10.1093/nar/gkx932. PMid:29040670.

LIAO, C., CHEN, M., CHEN, Y., WANG, T., SHEU, Z., KUO, K., CHANG, P.L., CHUNG, K. and LEE, M., 2012. Characterization of three Colletotrichum acutatum isolates from Capsicum spp. European Journal of Plant Pathology, vol. 133, no. 3, pp. 599-608. http:// dx.doi.org/10.1007/s10658-011-9935-7.

LIMA, J.S., FIGUEIREDO, J.G., GOMES, R.G., STRINGARI, D., GOULIN, E.H., ADAMOSKI, D., KAVA-CORDEIRO, V., GALLI-TERASAWA, L.V. and GLIENKE, C., 2012. Genetic diversity of Colletotrichum spp. an endophytic fungi in a medicinal plant, brazilian pepper tree. International Scholarly Research Network, vol. 2012, pp. 1-7. https://dx.doi.org/10.5402\%2F2012\%2F215716.

LIU, C., LI, M., REDDA, E.T., MEI, J., ZHANG, J., WU, B. and JIANG, X., 2019. A novel double-stranded RNA mycovirus isolated from Trichoderma harzianum. Virology Journal, vol. 16, no. 1, pp. 113. http://dx.doi.org/10.1186/s12985-019-1213-x. PMid:31511029.

MÁRQUEZ, L.M., REDMAN, R.S., RODRIGUEZ, R.J. and ROOSSINCK, M.J., 2007. A virus in a fungus in a plant: three-way symbiosis required for thermal tolerance. Science, vol. 315, no. 5811, pp. 513515. http://dx.doi.org/10.1126/science.1136237. PMid:17255511.

MARZANO, S.L., NELSON, B.D., AJAYI-OYETUNDE, O., BRADLEY, C.A., HUGHES, T.J., HARTMAN, G.L., EASTBURN, D.M. and DOMIER, L.L., 2016. Identification of diverse mycoviruses through metatranscriptomics characterization of the viromes of five major fungal plant pathogens. Journal of Virology, vol. 90, no. 15, pp. 6846-6863. http://dx.doi.org/10.1128/JVI.00357-16. PMid:27194764.

MILGROOM, M.G. and HILLMAN, B.I., 2011. The ecology and evolution of fungal viruses. In: D.J. HURST, ed. Studies in viral ecology: microbial and botanical host systems. New Jersey: Wiley-Blackwell, Chap. 9, vol. 1, pp. 217-253. http://dx.doi. org/10.1002/9781118025666.ch9.

NUSS, D.L., 2005. Hypovirulence: mycoviruses at the fungal-plant interface. Nature Reviews. Microbiology, vol. 3, no. 8, pp. 632642. http://dx.doi.org/10.1038/nrmicro1206. PMid:16064055.

OKADA, R., ICHINOSE, S., TAKESHITA, T., URAYAMA, S., FUKUHARA, T., KOMATSU, K., ARIE, T., ISHIHARA, A., EGUSA, M., KODAMA, M. and MORIYAMA, H., 2018. Molecular characterization of a novel mycovirus in Alternaria alternata manifesting two-sided effects: down-regulation of host growth and upregulation of host plant pathogenicity. Virology, vol. 519, pp. 23-32. http:// dx.doi.org/10.1016/j.virol.2018.03.027. PMid:29631173.

OLIVÉ, M. and CAMPO, S., 2021. The dsRNA mycovirus ChNRV1 causes mild hypervirulence in the fungal phytopathogen Colletotrichum higginsianum. Archives of Microbiology, vol. 203, no. 1, pp. 241-249. http://dx.doi.org/10.1007/s00203-02002030-7. PMid:32914229.

ÖZKAN, S. and COUTTS, R.H., 2015. Aspergillus fumigatus mycovirus causes mild hypervirulent effect on pathogenicity when tested on Galleria mellonella. Fungal Genetics and Biology, vol. 76, pp. 2026. http://dx.doi.org/10.1016/j.fgb.2015.01.003. PMid:25626171. 
PAOLETTI, M. and SAUPE, S.J., 2009. Fungal incompatibility: evolutionary origin in pathogen defense? BioEssays, vol. 31, no. 11, pp. 1201-1210. http://dx.doi.org/10.1002/bies.200900085. PMid:19795412.

PEARSON, M.N., BEEVER, R.E., BOINE, B. and ARTHUR, K., 2009. Mycoviruses of filamentous fungi and their relevance to plant pathology. Molecular Plant Pathology, vol. 10, no. 1, pp. 115-128. http://dx.doi.org/10.1111/j.1364-3703.2008.00503.x.

PICARELLI, M.A.S.C., GOBATTO, D., PATRÍCIO, F., RIVAS, E.B. and COLARICCIO, A., 2017. Virus infecting phytopathogenic fungi. Arquivos do Instituto Biológico, vol. 84, pp. 1-15. http://dx.doi. org/10.1590/1808-1657000162016.

RAWLINSON, C.J., CARPENTER, J.M. and MUTHYALU, D.G., 1975. Double-stranded RNA virus in Colletotrichum lindemuthianum. Transactions of the British Mycological Society, vol. 65, no. 2, pp. 305-341. http://dx.doi.org/10.1016/S0007-1536(75)80014-3.

ROBIN, C. and HEINIGER, U., 2001 [viewed 21 February 2021]. Chestnut blight in Europe: diversity of Cryphonectria parasitica, hypovirulence and biocontrol. Forest Snow and Landscape Research [online], vol. 76, no. 3, pp. 361-367. Available from: https://www.dora.lib4ri.ch/wsl/islandora/object/wsl\%3A15319/ datastream/PDF/Robin-2001-Chestnut_blight_in_Europe\%28published_version\%29.pdf

ROSSETO, P., COSTA, A.T., POLONIO, J.C., DA SILVA, A.A., PAMPHILE, J.A. and AZEVEDO, J.L.. 2016. Investigation of mycoviruses in endophytic and phytopathogenic strains of Colletotrichum from different hosts. Genetics and Molecular Research, vol. 15, no. 1, pp. 15017651. http://dx.doi.org/10.4238/gmr.15017651. PMid:26985921.

SEGERS, G.C., VAN WEZEL, R., ZHANG, X., HONG, Y. and NUSS, D.L., 2006. Hypovirus papain-like protease p29 suppresses RNA silencing in the natural fungal host and in a heterologous plant system. Eukaryotic Cell, vol. 5, no. 6, pp. 896-904. http:// dx.doi.org/10.1128/EC.00373-05. PMid:16757737.

SHAH, U.A., KOTTA-LOIZOU, I., FITT, B.D.L. and COUTTS, R.H.A., 2020. Mycovirus-induced hypervirulence of Leptosphaeria biglobosa enhances systemic acquired resistance to Leptosphaeria maculans in Brassica napus. Molecular Plant-Microbe Interactions, vol. 33, no. 1, pp. 98-107. http://dx.doi.org/10.1094/MPMI-09-190254-R. PMid:31652089.

SON, M., YU, J. and KIM, K.H., 2015. Five questions about mycoviruses. PLoS Pathogens, vol. 11, no. 11, pp. 1005172. http://dx.doi. org/10.1371/journal.ppat.1005172. PMid:26539725.

SUTTON, B.C., 1992. The genus Glomerella and its anamorph Colletotrichum. In: J.A BAILEY and M.J.JEGER, eds. Colletotrichum: biology, pathology and control. Wallingford: CAB International, pp. 1-26.

TRAN, T.T., LI, H., NGUYEN, D.Q., JONES, M.G.K. and WYLIE, S.J., 2019. Co-infection with three mycoviruses stimulates growth of a Monilinia fructicola isolate on nutrient medium, but does not induce hypervirulence in a natural host. Viruses, vol. 11, no. 89, pp. 1-11. http://dx.doi.org/10.3390/v11010089. PMid:30669656.

VAINIO, E.J., CHIBA, S., GHABRIAL, S.A., MAISS, E., ROOSSINCK, M., SABANADZOVIC, S., SUZUKI, N., XIE, J. and NIBERT, M., and ICTV REPORT CONSORTIUM, 2018. ICTV Virus Taxonomy Profile: partitiviridae. The Journal of General Virology, vol. 99, no. 1, pp. 17-18. http://dx.doi.org/10.1099/jgv.0.000985. PMid:29214972.
VAN DIEPENINGEN, A.D., DEBETS, A.J. and HOEKSTRA, R.F., 2006. Dynamics of dsRNA mycoviruses in black Aspergillus populations. Fungal Genetics and Biology, vol. 43, no. 6, pp. 446-452. http:// dx.doi.org/10.1016/j.fgb.2006.01.014. PMid:16546419.

WANG, S., ONGENA, M., QIU, D. and GUO, L., 2017 [viewed 21 February 2021]. Fungal viruses: promising fundamental research and biological control agents of fungi. SM Virology [online], vol. 2, no. 1, pp. 1011-1015. Available from: https://smjournals.com/ virology/fulltext/smjv-v2-1011.php

WANG, S., ZHANG, J., LI, P., QIU, D. and GUO, L., 2016. TranscriptomeBased discovery of Fusarium graminearum stress responses to FgHV1 infection. International Journal of Molecular Sciences, vol. 17, no. 11, pp. 1922. http://dx.doi.org/10.3390/ijms18010001. PMid:27869679.

WANG, Y., LIU, S., ZHU, H.J. and ZHONG, J., 2019. Molecular characterization of a novel mycovirus from the plant pathogenic fungus Colletotrichum gloeosporioides. Archives of Virology, vol. 164, no. 11, pp. 2859-2863. http://dx.doi.org/10.1007/s00705019-04354-2. PMid:31385115.

WU, M., ZHANG, L., LI, G., JIANG, D. and GHABRIAL, S.A., 2010. Genome characterization of a debilitation-associated mitovirus infecting the phytopathogenic fungus Botrytis cinerea. Virology, vol. 406, no. 1, pp. 117-126. http://dx.doi.org/10.1016/j. virol.2010.07.010. PMid:20674953.

YAEGASHI, H., YOSHIKAWA, N., ITO, T. and KANEMATSU, S., 2013. A mycoreovirus suppresses RNA silencing in the white root rot fungus, Rosellinia necatrix. Virology, vol. 444, no. 1-2, pp. 409-416. http://dx.doi.org/10.1016/j.virol.2013.07.010. PMid:23896640.

YU, J., PARK, J.Y., HEO, J.I. and KIM, K.H., 2020. The ORF2 protein of Fusarium graminearum virus 1 suppresses the transcription of FgDICER2 and FgAGO1 to limit host antiviral defences. Molecular Plant Pathology, vol. 21, no. 2, pp. 230-243. http:// dx.doi.org/10.1111/mpp.12895. PMid:31815356.

YU, X., LI, B., FU, Y., JIANG, D., GHABRIAL, S.A., LI, G., PENG, Y., XIE, J., CHENG, J., HUANG, J. and YI, X., 2010. A geminivirus-related DNA mycovirus that confers hypovirulence to a plant pathogenic fungus. Proceedings of the National Academy of Sciences of the United States of America, vol. 107, no. 18, pp. 8387-8392. http:// dx.doi.org/10.1073/pnas.0913535107. PMid:20404139.

ZHAI, L., ZHANG, M., HONG, N., XIAO, F., FU, M., XIANG, J. and WANG, G., 2018. Identification and characterization of a novel hepta-segmented dsRNA virus from the phytopathogenic fungus Colletotrichum fructicola. Frontiers in Microbiology, vol. 9, pp. 754. http://dx.doi.org/10.3389/fmicb.2018.00754. PMid:29725323.

ZHONG, J., CHEN, D., LEI, X.H., ZHU, H.J., ZHU, J.Z. and DA GAO, B., 2014. Detection and characterization of a novel Gammapartitivirus in the phytopathogenic fungus Colletotrichum acutatum strain HNZJ001. Virus Research, vol. 190, pp. 104-109. http://dx.doi. org/10.1016/j.virusres.2014.05.028. PMid:25008759.

ZHONG, J., PANG, X.D., ZHU, H.J., GAO, B.D., HUANG, W.K. and ZHOU, Q., 2016. Molecular characterization of a trisegmented mycovirus from the plant pathogenic fungus Colletotrichum gloeosporioides. Viruses, vol. 8, no. 10, pp. 1-12. http://dx.doi. org/10.3390/v8100268. PMid:27690081.

ZHOU, T. and BOLAND, G.J., 1997. Hypovirulence and double-stranded RNA in Sclerotinia homeocarpa. Phytopathology, vol. 87, no. 2, pp. 147-153. http://dx.doi.org/10.1094/PHYTO.1997.87.2.147. PMid:18945134. 